\title{
INEQUALITY OF OPPORTUNITY AND GROWTH ${ }^{1}$
}

\author{
Gustavo A. Marrero (1) and Juan G. Rodríguez (2)
}

(1) Departamento de Análisis Económico (Universidad de La Laguna, Spain), FEDEA and CAERP

(2) Departamento Economía Aplicada (Universidad Rey Juan Carlos, Spain) and Instituto de Estudios Fiscales

\begin{abstract}
Theoretical models and empirical studies exploring the relationship between income inequality and growth reach a disappointing inconclusive answer. We postulate in this paper that one reason for this inconclusive result is that income inequality consist at least in two different sorts of inequality, inequality of opportunity and effort. These two types of inequality would affect growth through opposite channels. As a result, the relationship between income inequality and growth could be positive or negative depending on which kind of inequality is more relevant. We test this proposal using depurated data of the PSID database for 24 US states from 1980 to 2000 . We estimate regressions that relate growth with overall income inequality, inequality of opportunity and other widespread used control variables. We find robust support for a negative relationship between inequality of opportunity and growth and a positive relationship between growth and income inequality.
\end{abstract}

JEL Classification: D63, H00.

Key Words: income inequality; inequality of opportunity; economic growth.

February 2009, very preliminary draft (please, do not quote)

\footnotetext{
${ }^{1}$ This research has benefited from the Spanish Ministry of Science and Technology Projects SEJ200764700/ECON and SEJ2006-15172/ECON. The usual disclaimer applies.
} 


\section{INTRODUCTION}

An upsurge literature on income inequality and growth has emerged over the last two decades. The development of endogenous growth theory has provided the tools to handle the relationships between income inequality and economic growth within a dynamic equilibrium setting. Relaxing the representative-agent assumption raises two main questions. The first concerns the effects of income and wealth inequality on growth. The second addresses the reverse causation from growth to inequality, and disputes about the Kuznets (1955) hypothesis, according to which development and growth should eventually reduce income inequality.

We concentrate on the first channel of influence, that is, on the effects of income inequality on growth. In this respect, two sets of growth models have been proposed in the literature: models where inequality is necessary for growth and models where inequality is harmful for growth. As it will become clear in the next section, the prevalence of a positive or negative relationship between income inequality and growth from a theoretical perspective is not possible since income inequality may affect economic growth in both directions through many different channels. For example, wealth and human capital heterogeneity across individuals produces a negative relationship between income inequality and growth because capital markets are imperfect. Meanwhile, income inequality may courage peopleôs effort and, therefore, economic growth. In this manner, opposite forces give rise to a confusing picture of the relationship between economic growth and inequality. Worst still, the empirical evidence on the link from initial income inequality to future growth is mixed. Thus, there is a general inconclusiveness of cross-sectional and panel data studies of the relationship between income inequality and growth. In this respect, Ehrhart (2009) acknowledges in a recent survey on this topic that the overall rather disappointing 
econometric results suggest either that the data and instruments are not sufficient to estimate the true relationship between both dimensions or the transmission mechanisms really at work are different from those mentioned in the literature.

In this paper we propose the idea that some of the confusing issues in this field are due to the inequality concept under consideration. Income inequality is at least the result of heterogeneity in the personal endowments and also the result of heterogeneity in the exerted effort. $^{2}$ If we equalize incomes, greater equality of individual investments will increase growth but likely at the same time, unobservable effort borne by agents will be discouraged. However, if we equalise opportunities, greater equality of investments may be achieved without negative direct disincentive effects over individual effort.

Therefore, these two types of inequality ï effort and opportunity- affect growth through opposite channels. Namely, inequality of effort should launch growth since it incentives people to invest in effort and education meanwhile inequality of opportunity does not favored human capital accumulation of the more talented individuals in society so it harms growth. As a result, the relationship between income inequality and growth may be positive or negative depending on which kind of inequality is more relevant. Moreover, the relative relevance of each kind of inequality could vary across countries, with the degree of development and the time period considered.

Using depurated data of the Panel Survey Income Dynamics (PSID) database for 24 US states from 1980 to 2000, we have computed inequality of opportunity according to the Van de Gaer (1993) index. Then, we have regress growth on income inequality, inequality of opportunity and other widespread used control variables. We have found robust support for a negative relationship between inequality of opportunity and growth and a positive relationship between growth and overall income inequality. In 
fact, the positive effect of income inequality on growth increases its significance and coefficients when the inequality-of-opportunity index is included in the regressions. This result points out that income inequality is a composite measure that must be decompose before trying to estimate the relevance of each depicted theoretical channel of inequality influence upon growth.

The paper is organized as follows. In the next section we briefly summarize the literature on this topic. In section 3, we present the inequality of opportunity measurement. Section 4 deals with the empirical model. The results are presented in section 5 and the paper concludes in section 6.

\section{PREVIOUS LITERATURE}

Two sets of growth models have been proposed in the literature:

1) Models where inequality is necessary for growth. There are three theoretical ways in which income inequality can encourage economic growth.

Savings: Income inequality is fundamentally good for the accumulation of a surplus over present consumption whether the rich have a marginal propensity to save higher than that of the poor (Kaldorô hypothesis). Then, more unequal economies growth faster than economies characterised by a more equitable income distribution if economic growth is related to the proportion of national income that is saved (see, among others, Galenson and Leibenstein, 1955). Stiglitz (1969) and Bourguignon (1981) formalised this argument in a Solow growth model with a linear saving function and a convex saving function, respectively.

\footnotetext{
${ }^{2}$ Another possible source of income inequality that we have not considered in this paper is inequality of luck.
} 
Investment indivisibilities: investment projects often involve large sunk costs. Wealth needs to be sufficiently concentrated in order for an individual to be able to initiate a new industrial activity. Barro (2000) proposes a similar argument for education. Individual investments in human capital have to go beyond a fixed degree to affect growth in a positive manner. If capital markets are imperfect, wealth will be concentrated and human capital investments and, therefore, growth will be increased. Incentives: There is an inescapable trade-off between equality of incomes and productive efficiency. On the one hand, following Mirrless (1971), in a moral hazard context where output depends on the unobservable effort borne by agents, rewarding the employees with a constant wage independent from output performance will discourage them from investing any effort. Hence, redistribution has a direct effect on growth. It reduces differences in income and, as a result, lowers the rate of growth. On the other hand, redistribution has an indirect effect on growth. Income redistribution that is financed through an income tax diminishes the incentives to accumulate wealth. Rebelo (1991) formalises this argument in a Ramsey-Cass-Koopmans growth model with perfect capital markets.

2) Models where inequality is harmful for growth. There are three main different subsets of models.

Models of economic development: Four general arguments, although not in a formalized way, can be found in the Economic Development literature (see, for example, Todaro, 1997).

a) Unproductive investment by the rich (see Mason, 1988).

b) Lower levels of human capital, nutrition and health by the poor (see Dasgupta and Ray, 1987). 
c) Demand pattern of the poor being more biased towards local goods (see, Marshall, 1988).

d) Political rejection by the masses

Models of political economy: They concern the link between market-generated income inequality and the extent of redistribution. This approach includes two components. The first component is a political mechanism through which greater income inequality leads to greater redistribution, and thus, more distortionary taxation. The median voter income will be, in more unequal societies, relatively poorer in relation to mean income. If the fiscal system is progressive, the more unequal is the income distribution, the more the median voter has to gain from taxes, and the more likely she or he is to vote for higher taxes. The second component is an economic mechanism through which the distortionary taxation reduces growth. See, among others, Perotti (1992, 1993), Alesina and Rodrik (1994), Alesina and Perotti (1994), Persson and Tabellini (1994) and González-Páramo (1994).

\section{Models of imperfect capital markets.}

a) When credit is scarce and costly, equilibrium investments under laissez-faire will remain unequal across individuals with heterogeneous human-capital endowments. But greater inequality between individual investments for a given aggregate capital stock will reduce aggregate output because of decreasing returns. Then, there is a role for suitably designed redistribution policies in enhancing aggregate productive efficiency and growth. See, for example, Galor and Zeira (1993) and Benabou (1996a).

b) Banerjee and Newman (1991) and Aghion and Bolton (1997) introduce moralhazard considerations as the explicit source of credit-market imperfections. 
Effort is increasing in the wealth of the individual. The more an individual needs to borrow, the less incentives she has to supply effort, in that she must share a larger fraction of the marginal returns from her effort with lenders. Redistributing wealth towards borrowers will have a positive effect on their effort incentives.

c) Macroeconomic volatility may be another channel through which inequality might affect economic growth. Alesina and Perotti (1996) justify this channel in terms of political instability. Aghion et al. (1999) postulate that inequality (in this case, unequal access to investment opportunities across individuals), together with a high degree of capital market imperfection, can generate persistent cycles.

The empirical analysis of the relationship between income inequality and growth is not conclusive. In general terms, cross-section analysis finds a negative relationship between both variables. See, for example, Alesina and Rodrik (1994), Persson and Tabellini (1994), Clarke (1995), Perotti (1996), Alesina and Perotti (1996), Alesina et al. (1996).

However, other authors find a positive relationship between growth and income inequality. For example, see Partridge (1997) for the United States, Zou and Li (1998) and Forbes (2000). Furthermore, Barro (2000) finds a very slight relationship between both variables when using panel data. Székely and Hilgert (1999) point out that this relationship depends on the inequality index that is used. Galindo (2004) finds a quadratic relationship between economic inequality and growth. That is, a negative relationship for low levels of concentration in the income distribution and a positive relationship for high levels of inequality. 
Moreover, the empirical evidence of the redistributionôs role in this matter is unclear. Bertola (1993), Perotti (1993), Alesina and Rodrik (1994), Persson and Tabellini (1994) and Milanovic (2000) find a positive relationship between countries with greater inequality and distortionary redistribution. At the same time, Bénabou (1996a, 1996b), Perotti (1996) and Bourguignon and Verdier (2000) find exactly the contrary relationship between the inequality variable and redistribution.

\section{INEQUALITY OF INCOME AND OPPORTUNITY MEASUREMENT}

Two different conceptions of equality of opportunity appear in the literature. A widely accepted conception of equality of opportunity is about the implementation of a meritocracy: only merits matter (see, for example, Lucas, 1995). A second conception, which has been developed over the last decade (see, among others, Roemer, 1993, 1996, 1998 and 2002, Van de Gaer, 1993, Fleurbaey, 1995, Roemer et al., 2003, RuizCastillo, 2003, Peragine, 2002 and 2004, Lefranc et al., 2006a and 2006b, MorenoTernero, 2007, Ooghe et al., 2007, Fleurbaey and Maniquet, 2007, and Rodríguez, 2009), considers that equal opportunity policies must create a ñlevel playing fieldò, after which individuals are on their own. That is, outcome differentials must only reflect individual differentials in effort. The first view corresponds to the case where individuals are completely responsible for their advantage. The ñlevel playing fieldò principle recognizes that an individualôs income is a function of variables beyond and within the individualôs control, called circumstances and effort, respectively. Inequality of opportunities refers to those income inequalities due exclusively to differential circumstances.

We focus in the second approach but first we provide some notation and definitions. 


\subsection{Methodology}

Let the members of a population enjoy a certain kind of advantage $u$, for example, income, life expectancy or wage-earning capacity. This advantage is a function of the amount of effort $e$ they expend and the amount of resources they consume $x$. Moreover, population is partitioned into a set of types $t=\{1$, é , T $\}$, where all individuals in a type have the same set of circumstances. Therefore, the achieved level of advantage enjoyed by an individual of type $t$ is $u^{\mathrm{t}}(x, e)$.

Suppose that there exists an amount $w$ per capita of the resource to allocate among individuals. In order to achieve equality of opportunity, society must choose a policy for allocating $w$ among the population. Let $\varphi^{\mathrm{t}}: \mathbb{R}_{+} \rightarrow \mathbb{R}_{+}$be an allocation rule that indicates the amount of the resource that an individual of type $t$ receives as a function of the effort she/he exerts. Then, the T-tuple $\varphi=\left(\varphi^{1}, \ldots, \varphi^{T}\right) \in \Phi$ is the policy of the social planner, where $\Phi$ is the set of feasible policies.

Finally, assume that the distribution of effort exerted by individuals of type $t$ is $F_{\varphi}^{t}$ and that $e^{t}(\pi, \varphi)$ is the level of effort exerted by the individual at the $\pi^{t h}$ quantile of that effort distribution when facing the policy $\varphi .^{3}$ We may hence define the indirect advantage function as follows:

$$
v^{t}(\pi, \varphi)=u^{t}\left(\varphi^{t}\left(e^{t}(\pi, \varphi)\right), e^{t}(\pi, \varphi)\right)
$$

\footnotetext{
${ }^{3}$ Note that the level of effort depends on the whole policy not just the allocation rule for type $t$ (see Roemer, 2003, for this generalization).
} 
In what follows, we assume that $\pi$ is a discrete variable but the analogous result applies, mutatis mutandis, to an infinite set.

According to the equality of opportunity from Roemerô pragmatic approach (1993, 1998, 2002 and 2003), two persons of different types have tried equally hard if and only if they are on the same rank of their respective effort distributions. ${ }^{4}$ Then, a policy that equalizes opportunities is a policy that equalizes advantage across types, for given quantiles of effort expended. At this point, Roemer proposes to maximize the minimum level of advantage, across types, of individuals who exert the same degree of effort $\pi^{\text {th. }}$

$$
\varphi_{\pi}^{R}=\arg \max _{\varphi \in \Phi}\left\{\min _{t \in T} v^{t}(\pi ; \varphi)\right\}
$$

Typically, we will have a different policy for each quantile. To adopt a compromise between so hypothetical a bundle of policies, Roemer proposes to give the same weight to each tranche as follows:

$$
\varphi^{R}=\arg \max _{\varphi \in \Phi}\left\{\frac{1}{Q} \sum_{\pi=1}^{Q} \min _{t \in T} v^{t}(\pi ; \varphi)\right\}
$$

where $Q$ is the number of quantiles; for example, $Q=100$ for centiles.

An alternative program has been proposed in Van de Gaer (1993). This approach focuses on the set of outcomes available to the members of each type (opportunity set).

\footnotetext{
${ }^{4}$ The use of rank $\pi$ as an interpersonally comparable measure of effort is precisely justified in Roemer (2003).
} 
The proposed policy maximizes the minimum of type-averages of the objective, over types:

$$
\varphi^{V}=\arg \max _{\varphi \in \Phi} \min _{t \in T}\left\{\frac{1}{Q} \sum_{\pi=1}^{Q} v^{t}(\pi ; \varphi)\right\} .
$$

We will consider this approach in this paper because it is the lees data intensive technique to measure inequality of opportunity.

Recently, different approaches have been proposed in the literature to take into account all the outcomes at each quantile, not just the minimum outcome. Peragine (2004) proposed two different methods to make ordinal welfare comparisons for income distributions according to equality of opportunity. In the first method, the Generalized Lorenz Curve at each quantile for both income distributions must be compared, so $Q$ different dominance conditions should be checked. If the number of quantiles, which must be examined to guarantee a close approximation of the effort exercised, is large, the application of this method may be too laborious. In the second method, the Generalized Lorenz Curve of the outcome distribution, in which each individual receives the mean of his/her type, must be compared. Dominance according to this method is a much less demanding criterion; in fact, dominance according to the first approach implies dominance according to the second method. However, this second method does not take into account dispersion within types. ${ }^{5}$

Moreno-Ternero (2007) provides (from a pure equity framework) some alternative mechanisms to construct equality-of-opportunity policies. A first mechanism considers that an equality-of-opportunity policy must minimize the average of advantage

\footnotetext{
${ }^{5}$ This can cause some problems. For example, assume two different outcome distributions with two types. In the first distribution, there is equality of opportunity. In the second distribution, type means are alike but there is some inequality of opportunity. If we apply the proposed method, we will conclude that both distributions are equivalent.
} 
inequality (across types) at each relative effort level. Thus, program (3) comes under this proposal:

$$
\varphi^{M T 1}=\arg \min _{\varphi \in \Phi} \frac{1}{Q} \sum_{\pi=1}^{Q} I\left(v^{1}(\pi ; \varphi), \ldots, v^{T}(\pi ; \varphi)\right)
$$

where $I(\cdot)$ is an inequality index. A second proposal minimizes the maximum inequality throughout the different levels of relative effort. ${ }^{6}$ In formal terms, this program is as follows:

$$
\varphi^{M T 2}=\arg \min _{\varphi \in \Phi}\left\{\max _{\pi} I\left(v^{1}(\pi ; \varphi), \ldots, v^{T}(\pi ; \varphi)\right)\right\}
$$

Notice that Moreno-Ternero (2007) assumes that policies in $\Phi$ allocate the available resource $w$ completely among individuals. In this manner, he rules out the policy that gives zero to every type, which might reach a higher (but undesirable) degree of equality. For the same reason, I make the same assumption throughout the paper.

Lefranc et al. (2006a) propose a mechanism to contrast equality of opportunity in a model that considers not only circumstances and effort, but also luck. They contrast strict equality of opportunity (outcome distributions conditional on effort are equal) and weak equality of opportunity (there are not unanimous preferences over the range of possible circumstances for all possible increasing utility functions that exhibit risk

\footnotetext{
${ }^{6} \mathrm{He}$ also proposes to minimize the inequality between the average outcome of each type of individual. This program, however, is not considered because it does not allow (as in the Van de Gaer approach) the treatment of individual advantage by relative levels of effort.
} 
aversion) by using the first and second stochastic dominance criterions. ${ }^{7}$ Unfortunately, as the authors acknowledge, this characterization of equality of opportunity does not allow us to rank situations in which equality of opportunity is rejected. To avoid this problem, they propose a new index to measure the degree of inequality of opportunity (see Lefranc et al., 2006b). In what follows, we consider luck, in any form, as a circumstance that must be compensated. $^{8}$

\subsection{US Data}

Data requirements for comparing inequality of opportunity across states or countries turn out to be even more stringent than for comparing inequality of outcome. Indeed, the reliability of the empirical analysis calls not only for comparable measures of individual disposable income. It also requires that individual background be measured in a comparable and homogeneous way across states or countries. As far we are aware, there are only few and recent national databases with information on individual circumstances, beside information on individual income. Thus, the data used in Roemer et al. (2003) and Lefranc et al., (2006) contain information on 11 developed countries: Belgium (1992), Denmark (1993), France (1994), Great Britain (1991), Italy (1993), The Netherlands (1995), Norway (1995), Spain (1991), Sweden (1991), the United States (1991) and West Germany (1994). Rodríguez, (2008) also uses the ECV (Survey on Living Conditions) dataset for Spain (2005) to evaluate equality of opportunity. Moreover, Cogneau and Mesplé-Somps (2009) study equality of opportunity for the following African countries: Ivory Cost (1985 and 1988), Ghana (1988 and 1998),

\footnotetext{
${ }^{7}$ Recall that second-order stochastic dominance is equivalent to generalized Lorenz dominance (Shorrocks, 1983).

${ }^{8}$ Dworkin (1981a and 1981b) claims that option luck (luck that is avoidable) should not be compensated. On the contrary, Fleurbaey (1995), and other authors, have provided arguments for full compensation for this type of luck. Moreover, libertarians, according to their strong form of self-ownership, consider that genetic luck must not be compensated (see, for example, Nozick, 1977).
} 
Guinea (1994), Madagascar (1993) and Uganda (1992). ${ }^{9}$ Despite these studies, the number of available observations (number of national databases) is not large enough to study the incidence of inequality of opportunity on economic growth. Note that we need the value of inequality of opportunity at least for two different periods of time, usually at the beginning of a decade, otherwise is quite difficult to appreciate long-run relationships. A conclusion of all this is that so far it is not possible to study such a relationship at international level. However, the PSID database provides comparable data for USA at national level during the period 1968-2007. This database contains information not only on individual income and circumstances but also on the state of residence. In this manner, this data set is extremely valuable for the analysis of the incidence of opportunity on economic growth at a regional level when some care steps are adopted. Needless to say, that the fact that the PSID database is only representative at national level makes our approach a challenging task.

Three reasons for calculating the Gini and Theil indices of inequality from our database: $1^{\text {st }}$. It will allow us to compare the representativeness of our samples with data sets that are truly representative of the population in the states of USA. We will compare the results obtained in Partridge (1997) with the Gini index by states with the results we obtain with our samples by states from the PSID. We show that the differences in terms of regressions are few even when we realize that our samples are truncated.

$2^{\text {nd }}$. Cause we have truncated our samples to household heads between 25 and 50 years old we better approximate to the distribution of effort. In this manner, our indices of inequality are a more accurate measure of inequality of effort.

$3^{\text {rd }}$. We can take advantage of the exact decomposition of the Theil index. In particular, we know that the Theil index exactly decomposed into a between and a within indices.

\footnotetext{
9 We do not consider the case of Brazil that has been particularly investigated: Dunn (2003), Bourguignon, Ferreira and Menendez (2007) and Cogneau and Gignoux (2007) because their approach is
} 
It is easy to show that the between component is the inequality of opportunity index by Van de Gaer. Therefore, if we discount the inequality of opportunity index from the Theil index we will obtain inequality coming from the rest of causes (in principle, effort and luck). So we will be able to estimate how effort and opportunity influence growth. Moreover, we check the validity of our samples in the sense that the bias in terms of income distributions is not so heavy adopting the following decisions:

$1^{\text {st }}$. We disregard the 1970 sample to assure a larger sample size for each state. There are 2116 observation for USA as a whole meanwhile the number of observations is 3096 and 3843 in 1980 and 1990, respectively. Moreover, there are only 17 states in 1970 with more than 50 observations. Consequently, we only use data by states for 1980 and 1990.

$2^{\text {nd }}$. We disregard those states with less than 50 observations for the computation of inequality of opportunity indices. If this condition is imposed to the PSID database for 1980 and 1990, only 23 states remain: Arkansas, California, Florida, Georgia, Illinois, Indiana, Iowa, Kentucky, Louisiana, Maryland, Massachusetts, Michigan, Mississippi, Missouri, New Jersey, New York, North Carolina, Ohio, Pennsylvania, South Carolina, Tennessee, Texas and Virginia.

$3^{\text {rd }}$. We reproduce the main model of Partridge with our data. The results of regressions for the Gini index are similar to those of Partridge (1997) using a different source, a different period (1980-1990 Vs 1960-1980) and with data that are truncated. This implies that bias is not fundamental from a distributive point of view.

$4^{\text {th }}$. We compute standard errors by bootstrapping. Cowell and Flachaire (2007) find that bootstrap tests usually improve numerical performance. Moreover, with small sample sizes it could be better to use a bootstrap approach that guarantees a better level of approximation to the nominal confidence intervals (Davison and Hinkley, 2005). We 
provide the standard error estimates calculated by bootstrapping according to the formula (see, for example, Davison and Hinkley, 2005):

$\breve{\mathscr{E}}(\breve{\bar{E}})=\sqrt{\frac{1}{R-1} \sum_{r=1}^{R}\left(I^{*}-\bar{I}^{*}\right)^{2}}$

where $I$ is the inequality of opportunity index and $R$ is the number of replications. In our calculations we have assumed $R=1000$.

It is shown in Tables 1 and 2 that estimated standard errors are very good for indices of income inequality. Moreover, data requirements for comparing inequality of opportunity across states turn out to be even more stringent than for comparing inequality of outcome. Indeed, the reliability of the empirical analysis calls not only for comparable measures of individual disposable income. It also requires that individual background be measured in a comparable and homogeneous way across states. Bearing in mind these facts and the limited size of our samples we find that estimates of standard errors for indices of inequality of opportunity are reasonable precise.

$5^{\text {th }}$. We adopt a multiple analysis of sensitivity. We check if our main results are dependent on the database by estimating many different models.

$6^{\text {th }}$. We have to distinguish in the empirical part of the paper a first part where we work only with three groups and a second part where we work with six groups. 
Table 1. Inequality of income and opportunity (3 groups) in 1980.

\begin{tabular}{|c|c|c|c|c|c|}
\hline \multirow[b]{2}{*}{ State } & \multirow[b]{2}{*}{ Obs. } & \multicolumn{2}{|c|}{ Inequality of Income } & \multicolumn{2}{|c|}{$\begin{array}{l}\text { Inequality of } \\
\text { Opportunity }\end{array}$} \\
\hline & & Gini & Theil 0 & GiniOp & TheilOp \\
\hline Arkansas & 62 & 0.33424 & 0.22890 & 0.05217 & 0.02447 \\
\hline California & 288 & $\begin{array}{c}0.00792 \\
0.32272\end{array}$ & $\begin{array}{c}0.01075 \\
0.21533\end{array}$ & $\begin{array}{c}0.00739 \\
0.01955\end{array}$ & $\begin{array}{c}0.00126 \\
0.00105\end{array}$ \\
\hline Florida & 91 & $\begin{array}{c}0.00382 \\
0.42466\end{array}$ & $\begin{array}{c}0.00602 \\
033766\end{array}$ & $\begin{array}{c}0.00451 \\
0.05620\end{array}$ & $\begin{array}{c}0.00049 \\
0.01162\end{array}$ \\
\hline Florida & 91 & $\begin{array}{c}0.42466 \\
0.00801\end{array}$ & $\begin{array}{c}0.33 / 66 \\
0.01293\end{array}$ & $\begin{array}{c}0.05620 \\
0.01191\end{array}$ & $\begin{array}{c}0.01162 \\
0.00445\end{array}$ \\
\hline Georgia & 96 & 0.27988 & 0.23834 & 0.06035 & 0.00837 \\
\hline Illinois & 96 & $\begin{array}{c}0.00724 \\
0.31883\end{array}$ & $\begin{array}{c}0.02882 \\
0.19999\end{array}$ & $\begin{array}{c}0.01018 \\
0.03264\end{array}$ & $\begin{array}{c}0.00336 \\
0.00405\end{array}$ \\
\hline Indiana & 87 & $\begin{array}{c}0.00557 \\
0.32770\end{array}$ & $\begin{array}{c}0.00733 \\
0.21875\end{array}$ & $\begin{array}{c}0.00657 \\
0.00683\end{array}$ & $\begin{array}{c}0.00098 \\
0.00044\end{array}$ \\
\hline Iowa & 57 & $\begin{array}{c}0.00797 \\
0.33646\end{array}$ & $\begin{array}{c}0.01040 \\
0.20843\end{array}$ & $\begin{array}{c}0.00587 \\
0.08543\end{array}$ & $\begin{array}{c}0.00167 \\
0.03182\end{array}$ \\
\hline Kentucky & 53 & $\begin{array}{c}0.00705 \\
0.26658\end{array}$ & $\begin{array}{c}0.00840 \\
0.12608\end{array}$ & $\begin{array}{c}0.00826 \\
0.08316\end{array}$ & $\begin{array}{c}0.00081 \\
0.02915\end{array}$ \\
\hline Luisiana & 83 & $\begin{array}{c}0.00479 \\
0.39985\end{array}$ & $\begin{array}{c}0.00481 \\
0.44742\end{array}$ & $\begin{array}{c}0.00712 \\
0.09522\end{array}$ & $\begin{array}{c}0.00283 \\
0.11200\end{array}$ \\
\hline Maryland & 126 & $\begin{array}{c}0.01128 \\
0.30568\end{array}$ & $\begin{array}{c}0.02907 \\
0.21192\end{array}$ & $\begin{array}{c}0.01338 \\
0.03672\end{array}$ & $\begin{array}{c}0.00792 \\
0.00489\end{array}$ \\
\hline Massachusetts & 60 & $\begin{array}{c}0.01258 \\
0.31730\end{array}$ & $\begin{array}{c}0.02000 \\
0.17690\end{array}$ & $\begin{array}{c}0.01423 \\
0.07375\end{array}$ & $\begin{array}{c}0.00588 \\
0.02887\end{array}$ \\
\hline Michigan & 147 & $\begin{array}{c}0.00478 \\
0.34835\end{array}$ & $\begin{array}{c}0.00578 \\
0.36653\end{array}$ & $\begin{array}{c}0.00825 \\
0.03818\end{array}$ & $\begin{array}{c}0.00196 \\
0.00410\end{array}$ \\
\hline Misisipi & 122 & $\begin{array}{c}0.00598 \\
0.38898\end{array}$ & $\begin{array}{c}0.01553 \\
0.29497\end{array}$ & $\begin{array}{c}0.00722 \\
0.16660\end{array}$ & $\begin{array}{c}0.00227 \\
0.07019\end{array}$ \\
\hline Missouri & 95 & $\begin{array}{c}0.01821 \\
0.33638\end{array}$ & $\begin{array}{c}0.02564 \\
0.27555\end{array}$ & $\begin{array}{c}0.02441 \\
0.05990\end{array}$ & $\begin{array}{c}0.01609 \\
0.01270\end{array}$ \\
\hline New Jersey & 79 & $\begin{array}{c}0.00689 \\
0.37963\end{array}$ & $\begin{array}{c}0.01305 \\
0.31529\end{array}$ & $\begin{array}{c}0.00783 \\
0.06341\end{array}$ & $\begin{array}{c}0.00107 \\
0.04782\end{array}$ \\
\hline New York & 144 & $\begin{array}{c}0.00661 \\
0.34521\end{array}$ & $\begin{array}{c}0.01435 \\
0.23178\end{array}$ & $\begin{array}{c}0.00707 \\
0.01040\end{array}$ & $\begin{array}{c}0.00049 \\
0.00034\end{array}$ \\
\hline N. Carolina & 142 & $\begin{array}{c}0.00423 \\
0.36258\end{array}$ & $\begin{array}{c}0.00623 \\
0.24823\end{array}$ & $\begin{array}{c}0.00477 \\
0.05377\end{array}$ & $\begin{array}{c}0.00092 \\
0.01199\end{array}$ \\
\hline Ohio & 136 & $\begin{array}{c}0.00826 \\
0.29474\end{array}$ & $\begin{array}{c}0.01188 \\
0.17561\end{array}$ & $\begin{array}{c}0.01207 \\
0.01725\end{array}$ & $\begin{array}{c}0.00736 \\
0.00127\end{array}$ \\
\hline Pennsylvania & 162 & $\begin{array}{c}0.00372 \\
0.36375\end{array}$ & $\begin{array}{c}0.00638 \\
0.35750\end{array}$ & $\begin{array}{c}0.00563 \\
0.03235\end{array}$ & $\begin{array}{c}0.00051 \\
0.00356\end{array}$ \\
\hline S. Carolina & 152 & $\begin{array}{c}0.00663 \\
0.34084\end{array}$ & $\begin{array}{c}0.01534 \\
0.22259\end{array}$ & $\begin{array}{c}0.00725 \\
0.01944\end{array}$ & $\begin{array}{c}0.00210 \\
0.00139\end{array}$ \\
\hline Tennessee & 53 & $\begin{array}{c}0.00711 \\
0.27433\end{array}$ & $\begin{array}{c}0.01091 \\
0.16526\end{array}$ & $\begin{array}{c}0.00470 \\
0.06274\end{array}$ & $\begin{array}{c}0.00036 \\
0.01927\end{array}$ \\
\hline Texas & 187 & $\begin{array}{c}0.00597 \\
0.30064\end{array}$ & $\begin{array}{c}0.00902 \\
0.18843\end{array}$ & $\begin{array}{c}0.00599 \\
0.00945\end{array}$ & $\begin{array}{c}0.00193 \\
0.00038\end{array}$ \\
\hline Virginia & 116 & $\begin{array}{c}0.00426 \\
0.28231\end{array}$ & $\begin{array}{c}0.00774 \\
0.22889\end{array}$ & $\begin{array}{c}0.00473 \\
0.00805\end{array}$ & $\begin{array}{c}0.00025 \\
0.00035\end{array}$ \\
\hline USA & 3091 & $\begin{array}{l}0.00452 \\
\mathbf{0 . 3 4 0 8 4}\end{array}$ & $\begin{array}{c}0.01668 \\
\mathbf{0 . 2 5 2 5 2}\end{array}$ & $\begin{array}{c}0.00551 \\
\mathbf{0 . 0 2 9 8 7}\end{array}$ & $\begin{array}{c}0.00149 \\
\mathbf{0 . 0 0 1 7 9}\end{array}$ \\
\hline
\end{tabular}


Table 2. Inequality of income and opportunity (3 groups) in 1990.

\begin{tabular}{|c|c|c|c|c|c|}
\hline \multirow[b]{2}{*}{ State } & \multirow[b]{2}{*}{ Obs. } & \multicolumn{2}{|c|}{ Inequality of Income } & \multicolumn{2}{|c|}{ Inequality of Opportunity } \\
\hline & & Gini & Theil 0 & GiniOp & TheilOp \\
\hline Arkansas & 67 & 0.29706 & 0.16818 & 0.04990 & 0.00631 \\
\hline & & 0.00629 & 0.00934 & 0.00823 & 0.00185 \\
\hline California & 332 & 0.38229 & 0.29217 & 0.01847 & 0.00085 \\
\hline Florida & 129 & $\begin{array}{c}0.00486 \\
0.42208\end{array}$ & $\begin{array}{c}0.00831 \\
0.35338\end{array}$ & $\begin{array}{c}0.00565 \\
0.07434\end{array}$ & $\begin{array}{c}0.00122 \\
0.01538\end{array}$ \\
\hline & & 0.00645 & 0.01165 & 0.00937 & 0.00154 \\
\hline Georgia & 112 & 0.35784 & 0.26191 & 0.09089 & 0.01891 \\
\hline Illinois & 115 & $\begin{array}{c}0.00725 \\
034540\end{array}$ & $\begin{array}{c}0.01292 \\
034581\end{array}$ & $\begin{array}{c}0.01072 \\
0.05836\end{array}$ & $\begin{array}{c}0.00403 \\
0.00767\end{array}$ \\
\hline & & 0.00661 & 0.01626 & 0.00753 & 0.00090 \\
\hline Indiana & 89 & 0.33431 & 0.22422 & 0.06433 & 0.01268 \\
\hline Iowa & 72 & $\begin{array}{c}0.00798 \\
0.32327\end{array}$ & $\begin{array}{c}0.01160 \\
0.20573\end{array}$ & $\begin{array}{c}0.00693 \\
0.02769\end{array}$ & $\begin{array}{c}0.00305 \\
0.00201\end{array}$ \\
\hline Kentucky & 69 & $\begin{array}{c}0.00672 \\
0.32882\end{array}$ & $\begin{array}{c}0.00943 \\
0.22694\end{array}$ & $\begin{array}{c}0.01006 \\
0.05614\end{array}$ & $\begin{array}{c}0.00337 \\
0.01003\end{array}$ \\
\hline Luisiana & 78 & $\begin{array}{c}0.00606 \\
0.38272\end{array}$ & $\begin{array}{c}0.01171 \\
0.46783\end{array}$ & $\begin{array}{c}0.00837 \\
0.02394\end{array}$ & $\begin{array}{c}0.00243 \\
0.00203\end{array}$ \\
\hline Maryland & 155 & $\begin{array}{c}0.01027 \\
0.49677\end{array}$ & $\begin{array}{c}0.03272 \\
0.47258\end{array}$ & $\begin{array}{c}0.01231 \\
0.04735\end{array}$ & $\begin{array}{c}0.00635 \\
0.00955\end{array}$ \\
\hline Massachusetts & 89 & $\begin{array}{c}0.02059 \\
0.33443\end{array}$ & $\begin{array}{c}0.03707 \\
0.20076\end{array}$ & $\begin{array}{c}0.02261 \\
0.07286\end{array}$ & $\begin{array}{c}0.01078 \\
0.01554\end{array}$ \\
\hline Michigan & 177 & $\begin{array}{c}0.00575 \\
0.42317\end{array}$ & $\begin{array}{c}0.00663 \\
0.43608\end{array}$ & $\begin{array}{c}0.00762 \\
0.02571\end{array}$ & $\begin{array}{c}0.00144 \\
0.00205\end{array}$ \\
\hline Misisini & 162 & $\begin{array}{c}0.00771 \\
0.37041\end{array}$ & $\begin{array}{c}0.01571 \\
033277\end{array}$ & $\begin{array}{c}0.01007 \\
005999\end{array}$ & $\begin{array}{c}0.00569 \\
0.01015\end{array}$ \\
\hline & & 0.00857 & 0.01695 & 0.01082 & 0.00368 \\
\hline Missouri & 113 & $\begin{array}{c}0.33655 \\
0.00567\end{array}$ & $\begin{array}{c}0.23957 \\
0.01008\end{array}$ & $\begin{array}{c}0.04331 \\
0.00914\end{array}$ & $\begin{array}{c}0.00525 \\
0.00295\end{array}$ \\
\hline New Jersey & 101 & 0.47989 & 0.46021 & 0.09108 & 0.02703 \\
\hline New York & 160 & $\begin{array}{c}0.01661 \\
0.30540\end{array}$ & $\begin{array}{c}0.02897 \\
0.18871\end{array}$ & $\begin{array}{c}0.01946 \\
0.01377\end{array}$ & $\begin{array}{c}0.00932 \\
0.00130\end{array}$ \\
\hline $\mathrm{N}$ Carolina & 214 & $\begin{array}{c}0.00425 \\
0.37127\end{array}$ & $\begin{array}{c}0.00535 \\
0.28901\end{array}$ & $\begin{array}{c}0.00367 \\
0.01882\end{array}$ & $\begin{array}{c}0.00012 \\
0.00295\end{array}$ \\
\hline & & $\begin{array}{c}0.00716 \\
0 \quad 35475\end{array}$ & $\begin{array}{c}0.01244 \\
0 \quad 35219\end{array}$ & $\begin{array}{c}0.01080 \\
0.01183\end{array}$ & 0.00495 \\
\hline Ohio & 150 & $\begin{array}{c}0.35475 \\
0.00524\end{array}$ & $\begin{array}{c}0.35219 \\
0.01312\end{array}$ & $\begin{array}{c}0.01183 \\
0.00573\end{array}$ & $\begin{array}{c}0.00039 \\
0.00147\end{array}$ \\
\hline Pennsylvania & 205 & 0.36963 & 0.34179 & 0.02655 & 0.00207 \\
\hline S. Carolina & 225 & $\begin{array}{c}0.00441 \\
0.35308\end{array}$ & $\begin{array}{c}0.00967 \\
0.45366\end{array}$ & $\begin{array}{c}0.00444 \\
0.02613\end{array}$ & $\begin{array}{c}0.00126 \\
0.01089\end{array}$ \\
\hline Tennessee & 69 & $\begin{array}{c}0.00555 \\
0.43795\end{array}$ & $\begin{array}{c}0.02604 \\
0.38964\end{array}$ & $\begin{array}{c}0.00669 \\
0.11518\end{array}$ & $\begin{array}{c}0.00173 \\
0.03290\end{array}$ \\
\hline & & 0.01340 & 0.02403 & 0.01702 & 0.01141 \\
\hline Texas & 235 & 0.39419 & 0.35183 & 0.05256 & 0.00643 \\
\hline Virginia & 134 & $\begin{array}{c}0.00520 \\
0.35629\end{array}$ & $\begin{array}{c}0.01028 \\
0.27648\end{array}$ & $\begin{array}{c}0.00727 \\
0.08089\end{array}$ & $\begin{array}{c}0.00060 \\
0.02070\end{array}$ \\
\hline USA & 3843 & $\begin{array}{c}0.00548 \\
\mathbf{0 . 3 8 4 6 9} \\
0.0016\end{array}$ & $\begin{array}{c}0.01039 \\
\mathbf{0 . 3 2 6 6 6} \\
0.0054\end{array}$ & $\begin{array}{c}0.00835 \\
\mathbf{0 . 0 7 6 5 9}\end{array}$ & $\begin{array}{c}0.00377 \\
\mathbf{0 . 0 1 0 0 3}\end{array}$ \\
\hline
\end{tabular}




\section{THE EMPRIRICAL MODEL}

Our empirical model is based on Partridge (1997), Persson and Tabellini (1994) and Alesina and Rodrik (1994). We use a selected set of 24 states of the United States of America. The time span is $1980-2000$, limited by the availability of data and the problems we face to construct Inequality of Opportunity Indexes, as commented in the

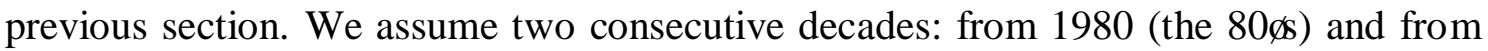
1990 to 2000 (the 900̂).

A panel data set of U.S. states offers several advantages to deal with the main purpose of this paper, which is to isolate the effect of inequality of opportunities on growth. For example, the political process, for the most part, is similar democratic across states. Institutional, cultural, religious and other differences are less intensive for U.S. states than for different countries.

We take the Partridge (1997) analysis as our benchmark. We follow this work to define the sub-samples and the dependent and independent variables. The dependent variable is per capita real personal income growth in the ensuing ten years of each sub-sample. The independent variables are all measured at the beginning of each decade. This strategy would save us from suffering from endogeneity and measurement errors, thus we apply standard pooling regressions techniques in our empirical study. As is the norm in the convergence literature, an implicit assumption is that economic growth is converging to an equilibrium growth path that is a function of the initial conditions. Hence, the lagged level of real per capita income is included in the model to control for conditional convergence across states.

For the benchmark model we use an overall inequality index measure at the beginning period. We consider the Gini and the Theil coefficients of before-tax family income 
inequality. These indexes are constructed as commented in Section 2. The Gini and the Theil index both fall between 0 and 1 and are positively related to total inequality. Although they are imperfect coefficients to measure income-inequality they have the advantage of being well known and measured at the state level. The inequality of opportunity index is the Van de Gaer (1993) measure. Although imperfect, these are the best and unique data to construct proxies for an inequality of opportunity indexes in an homogenous way and for a large enough set of cross sections units and time periods, which are required to carry out an empirical analysis on inequality and growth.

For each state, real per capita personal income is total real personal income (adjusted by CPI) divided by total midyear population. Population and personal income data comes from the Regional Economic Accounts of the BEA, ${ }^{10}$ while CPI data comes from the BLS, U.S. Department of Labour. ${ }^{11}$

In order to estimate the relationship between inequality and growth properly, the model must include additional variables that may also affect growth. Basically, we use the same controls than were used in Patridge. Roughly, they are a convergence term measured by a lagged term of real per capita income, time and regional controls, the average skills of the labour force measured by the maximum level of attained education, the sectoral composition measured by the share of employment in each sector and labour growth. Employment data (total and by type of industries) come from the Current Employment Statistics. ${ }^{12}$

Barro and Sala-i-Martin $(1992,1995)$ show that the gap between the wealthiest and poorest states converge at about 2 percent per year. Thus, the initial level of real per capita personal income in the decade (using the CPI) is used to control for economic

\footnotetext{
${ }^{10}$ U.S. Department of Commerce: http://www.bea.gov/regional/spi/drill.cfm

${ }^{11}$ All Urban Consumers CPI series: http://www.bls.gov/data/\#prices
} 
convergence across states. Following Barro and Sala-i- Martin, some specifications will also control for the initial industrial mix of the state. The shares of nonagricultural employment are included for mining; construction; manufacturing; transportation and public utilities; finance, insurance, and real estate; and the government. Traded goods and services are the omitted sector and, thus, the employment share coefficients should be interpreted as being relative to the trade and service sectors.

To account for the different importance of agriculture across states, the percent of the population that worked on a farm is also included.

We consider time dummies for the $80 \hat{a}$ and we omit the dummy of the $90 \hat{a}$, thus the time dummy of the $80 \hat{\mathrm{s}}$ is referred to that decade. We also use a standard and broad classification for regional dummy variables: West, North West, South and North East. The omitted regional dummy is the North East region. The average skills of the labour force are measured by the percent of the population over 24 years old that have graduated from high school, but not a four-year college, and by the percent that graduated from a four-year college. The percent of individuals who have not graduated from high school is the omitted category. ${ }^{13}$ Finalley, one channel through which inequality can reduce growth is by increasing welfare payments (Person and Tabellini, 1994). To control for this possibility, we include transfer payments from the government to the household as a percentage of householdôs income at the beginning of each decade (1980 and 1990). These data comes from the Statistical Abstract of the United States. $^{14}$

\footnotetext{
12 BLS, U.S. Department of Labour: http://www.bls.gov/data/\#employment

${ }^{13}$ Data of attained education are obtained from the Historical Census Statistics on Education attained in the U.S., 1940 to 2000 (U.S. Census Bureau) (http://www.census.gov/population/www/socdemo/education/introphct41.html)

${ }^{14}$ The State and Local Government Finances and Employment section: http://www.census.gov/prod/www/abs/statab1951-1994.htm
} 
The benchmark analysis is based on regressions between growth, lagged income, a general inequality index and a set of control variables. As a general index, we use both the Gini and the Theil coefficients:

$$
G Y_{i t}=\beta \cdot y_{i t-s}+\phi \cdot I_{i t-s}+\alpha^{\prime} T_{t}+\delta^{\prime} R_{i}+\lambda^{\prime} X_{i t-s}+\varepsilon_{i, t}
$$

where $\mathrm{GY}_{i t}$ is per capital real income growth in the decade; $y_{i t}$ is real per capita income of state $i$ at the beginning of the decade $t-s ; T_{t}$ is a set of time dummies (in our case only that of the $80 \hat{\mathrm{s}}) ; R_{i}$ is a set of regional dummies; The $I_{i t-s}$ is the overall inequality index measures at the beginning of the decade; finally, $X_{i t-s}$ is the set of control variables measured at the beginning of the decade. The regional dummies considers those fixed factors which are time-invariant and inherent to each area which are not observed or not included in the model, such as geographical, social or local policy regional aspects or initial technology efficiency; finally, $\cup_{t}^{\circ}$ encompasses effects of a random nature which are not considered in the model, which is assumed to have the standard error component structure.

Our contribution is based on distinguish between inequality and inequality of opportunities as two different channels affecting growth. To this goal, we estimate an extended model including both the overall inequality measure and an inequality of opportunity index. We denote this index by $\mathrm{IO}_{\mathrm{it}-\mathrm{s}}$, which is also measured at the beginning of the decade,

$$
G Y_{i t}=\beta \cdot y_{i t-s}+\phi_{1} \cdot I_{i t-s}+\phi_{2} \cdot I O_{i t-s}+\alpha^{\prime} T_{t}+\delta^{\prime} R_{i}+\lambda^{\prime} X_{i t-s}+\varepsilon_{i, t}
$$

\section{RESULTS}

Our benchmark analysis is based on regressions between growth, an overall inequality index and a set of control variables. As general inequality indexes, we use the Gini and 
the Theil coefficients. Our main contribution includes in this setting an Inequality of Opportunity (IO) index, check for robustness of inequality results and discuss the relationship between IO and growth.

Results are summarized in Table IV.1 and IV.2. Both show results using a standard OLS pooling regression technique and tests are based on White cross-section standard errors and covariance matrix, as in Patridge and many others. Endogeneity should not be a direct concern in these specifications since the independent variables are measured at the beginning of the decade, while the dependent variable is measured for the ensuing ten years. When controls are not included in the regression, the overall inequality and the IO coefficients could be biased by omitted factors that are correlated with both economic growth and initial-period income inequality. Hence, we focus on results of a full specified model, using all controls including in Partridge (1997): a convergence term, time and regional dummies, education variables, industry mix measures, farm population and government state variables. As commented in Section 2, we use a total of 24 states to carry out our study.

Table IV.1 summarizes results of our basic model, which includes an overall inequality index (the Gini and the Theil index). This benchmark analysis has also the purpose of checking the consistency of our results (with an alternative overall inequality measure, different decades and a selected set of states) with results in Partridgeôs paper. In a second stage, we include in the model regression the IO index and test its relationship with growth and its differences between the standard relationship between overall inequality and growth. Table IV.2 shows the results of these regressions. Results related to the control variables are basically the same than in Patridge and are robust to the model specification and the alternative inequality measures considered in the model. 
The negative initial level of per capita income coefficient reflects evidences of conditional convergence, in the line of Barro and Sala-i-Martin (1991) work. The dummy variable coefficients for the 1980's is non statistically different from zero. Regional dummy variables are included to capture omitted regional fixed effects that may affect growth. Cross-regional effects are reflected in the regional dummy coefficients. Our results suggest that the West and Midwest states include in the sample had clearly lower economic growth in relation to the North East regions. The coefficient of the South regions is also negative, but lower in magnitude than those of the West and Midwest.

The initial Gini and Theil coefficient is positive and significantly related to per capita income growth in the following ten years. This implies that states with greater overall economic inequality subsequently experienced greater economic growth. This result is consistent with Patridge, although the magnitude is different because we are using different decades, a reduced set of states and our Gini and Theil measure is based on PSD database in order to be homogenous with the inequality of opportunities measures.

It is expected that future economic growth and the labour force's initial level of human capital are positively related. The coefficient associated with the Bachelor variable is highly positive and significant, while that of High School is negative (but smaller in magnitude) and significant in general. These results are consistent with growth models augmented for human capital.

The beginning of the period industry employment shares capture industry mix effects. The coefficients on most of the nonfarm share variables are negative and significant. This suggests that states with greater initial shares in services and traded goods (the 
omitted category), a set of industries that grew rapidly nationally, experienced greater economic growth.

Similarly, states with larger government sectors may have higher taxes and fewer economic incentives. The public transfer share should directly test PT's (1994) claim that one path through which inequality reduces future economic growth is by increasing public payments. One route by which greater inequality reduces ensuing economic growth is that inequality results in greater transfer payments. In this manner, because income inequality affects economic growth indirectly through transfer payments, including this variable in the model should control for this indirect channel of the inequality-growth relationship. Our results shows that the coefficient associated to the transfer payment variable is significant in all specifications.

It is possible that growth in the previous decade could in turn influence growth in the following decade. Similarly, the Kuznets hypothesis suggests that the initial period Gini coefficient is influenced by the level of economic development, which is associated with economic growth in the previous decade. Both points suggest that economic activity in the previous decade should be accounted for. This is the reason why nonagricultural employment growth in the preceding decade (e.g., employment growth in the 1970's is used to explain per capita income growth in the 1980's). The coefficient associated to labour growth in the preceding year is positive and significant, which corroborates this thesis. 


\section{TABLE IV.1}

The Benchmark settin g: Overall inequalit y Vs. Growth

\begin{tabular}{|c|c|c|c|c|}
\hline & Estimates & $\mathrm{t}$-stat & Estimates & $\mathrm{t}$-stat \\
\hline Inequality (Theil) & 8.140 & 8.326 & -- & -- \\
\hline Inequality (Gini) & -- & & 11.941 & 44.183 \\
\hline I.Opportunity (TOP) & -- & & -- & -- \\
\hline Lagged Income & -0.004 & -5.433 & -0.004 & -4.278 \\
\hline High & -0.452 & -172.494 & -0.423 & -68.113 \\
\hline Bachelour & 1.058 & 3.161 & 1.043 & 2.542 \\
\hline 80 Dum & 0.409 & 2.076 & 0.256 & 1.038 \\
\hline South Dum & -1.653 & -6.204 & -1.621 & -4.569 \\
\hline MidWest Dum & -4.473 & -4.419 & -4.089 & -3.222 \\
\hline West Dum & -10.153 & -4.427 & -10.061 & -3.466 \\
\hline Mining & -1.513 & -1.997 & -1.405 & -1.400 \\
\hline Construction & -3.530 & -4.341 & -3.408 & -3.509 \\
\hline Manufacturing & -0.223 & -3.745 & -0.201 & -3.405 \\
\hline Transport & -1.668 & -5.539 & -1.519 & -6.907 \\
\hline Finance & 0.364 & 0.643 & 0.378 & 0.626 \\
\hline Government & -0.811 & -5.279 & -0.729 & -3.794 \\
\hline Farms & -0.717 & -18.562 & -0.821 & -27.440 \\
\hline Gov. Transfers & -0.718 & -5.490 & -0.701 & -4.182 \\
\hline Labor & 0.211 & 10.722 & 0.201 & 10.021 \\
\hline Constant term & 130.781 & 8.326 & 124.826 & 6.410 \\
\hline $\mathrm{R} 2$ & 0.7192 & & 0.7165 & \\
\hline Adjusted R2 & 0.5600 & & 0.5503 & \\
\hline F-test & 0.0002 & & 0.0002 & \\
\hline
\end{tabular}

We stress several results when including the IO measure in the regression (see Table IV.2). All results support our thesis that IO is harmful for growth, while inequality of effort is positively related.

We first notice that the IO coefficient is always negative and significant for all models. But in addition, the magnitude and the statistical significance of the coefficients on the Theil and Gini variables are increased in these models. Our interpretation is that the overall inequality index includes both an inequality of opportunity and an inequality of effort part. As commented, our IO index is imperfect, in the sense that it is capturing 
just a small part of the factors affecting IO. Hence, although controlling by our IO index, the Gini and the Theil inequality measures are not totally orthogonal to an ideal IO measure, but its coefficient is more in the direction of the inequality of effort than in the previous model specification. For this reason, now the coefficient associated to the Theil and the Gini are higher.

TABLE IV.2

Inequality, Inequality of Opportunities and Growth

\begin{tabular}{|c|c|c|c|c|c|c|}
\hline & Estimates & t-stat & Estimates & t-stat & Estimates & t-stat \\
\hline Inequality (Theil) & -- & -- & 9.458 & 6.452 & -- & -- \\
\hline Inequality (Gini) & -- & -- & -- & -- & 12.883 & 80.311 \\
\hline I.Opportunity (TOP) & -28.222 & -4.448 & -36.324 & -6.660 & -31.294 & -3.891 \\
\hline Lagged Income & -0.004 & -7.834 & -0.004 & -6.749 & -0.004 & -5.095 \\
\hline High & -0.443 & -10.995 & -0.471 & -103.915 & -0.435 & -33.393 \\
\hline Bachelour & 1.141 & 4.161 & 1.195 & 4.033 & 1.158 & 3.057 \\
\hline 80 Dum & 0.657 & 1.538 & 1.035 & 96.300 & 0.770 & 9.295 \\
\hline South Dum & -1.438 & -7.035 & -1.527 & -3.743 & -1.503 & -3.181 \\
\hline MidWest Dum & -3.871 & -3.007 & -4.264 & -4.073 & -3.855 & -2.866 \\
\hline West Dum & -9.925 & -4.380 & -10.126 & -5.146 & -10.019 & -3.844 \\
\hline Mining & -1.581 & -1.888 & -1.559 & -1.977 & -1.438 & -1.362 \\
\hline Construction & -2.818 & -3.084 & -3.279 & -3.956 & -3.155 & -3.172 \\
\hline Manufacturing & -0.247 & -3.797 & -0.254 & -7.763 & -0.226 & -6.800 \\
\hline Transport & -1.149 & -35.317 & -1.263 & -5.360 & -1.147 & -8.486 \\
\hline Finance & 0.097 & 0.183 & 0.137 & 0.253 & 0.179 & 0.303 \\
\hline Government & -0.843 & -4.650 & -0.914 & -7.572 & -0.808 & -4.745 \\
\hline Farms & -0.840 & -9.068 & -0.568 & -18.338 & -0.714 & -47.501 \\
\hline Gov. Transfers & -0.631 & -4.246 & -0.678 & -5.781 & -0.662 & -4.250 \\
\hline Labor & 0.178 & 7.370 & 0.203 & 6.253 & 0.191 & 5.713 \\
\hline Constant term & 125.606 & 6.901 & 128.897 & 9.391 & 122.535 & 6.823 \\
\hline $\mathrm{R} 2$ & 0.714 & & 0.727 & & 0.723 & \\
\hline Adjusted R2 & 0.553 & & 0.558 & & 0.550 & \\
\hline F-test & 0.000 & & 0.000 & & 0.000 & \\
\hline
\end{tabular}




\section{CONCLUDING REMARKS}

Models exploring the relationship between income inequality and economic growth do not reach a clear-cut conclusion. We have postulated in this paper that the main reason for this inconclusive result is that income inequality measures are indeed measuring at least two different sorts of inequality: inequality of opportunity and inequality of effort. Though this issue has been already emphasized in the equality-of-opportunity literature, this distinction has not been yet considered in the growth literature, likely due to the difficulty of using properly data.

In this paper we defend that these two types of inequality ï effort and opportunity- affect growth through opposite channels. Namely, inequality of effort should launch growth since it incentives people to invest in effort and education meanwhile inequality of opportunity does not favored human capital accumulation of the more talented individuals in society so it harms growth. As a result, the relationship between income inequality and growth may be positive or negative depending on which kind of inequality is more relevant. Moreover, the relative relevance of each kind of inequality could vary across countries, with the degree of development and the time period considered.

Using depurated data of the PSID database for 24 US states from 1980 to 2000, we have followed Van de Gaer (1993) to construct proxies of inequality of opportunity indexes. Although we realize the deficiencies of the dataset for this kind of studies, we consider that the analysis is still relevant because it is (arguable) the best disposable dataset for analyzing the relationship between inequality of opportunity and growth and several test previously checked upon the data have been successfully pass through. 
Running standard regressions which relate growth with an overall inequality index, an inequality of opportunity index and other widespread used control variables, we have found robust support for a negative relationship between inequality of opportunity and growth though a positive relationship (as it is standard for US data) between growth and overall income inequality. In fact, the positive effect of income inequality on growth increases its significance and coefficients when the inequality-of-opportunity index is included in the regressions. This result points out that income inequality is a composite measure that must be decompose before trying to estimate the relevance of each depicted theoretical channel of inequality influence upon growth.

The main conclusion of this paper goes in the following direction. In principle, empirical studies relating growth with an overall inequality measure can lead to any conclusion. It basically depends on what is more important in the index: the inequality of opportunity or the inequality of effort part. For example, Barro (2000) shows a positive relationship between growth and inequality within most developed countries, while this relationship turns negative when looking at poorest countries. This can be due to the fact that inequality of opportunities is more important within less developed countries, while the part of inequality explained by the inequality of effort is more important in rich countries.

Hence, we suggest that the effort of understanding this crucial macroeconomic relationship could be in vain unless we previously make clear at least the distinction between inequality of opportunity and effort. We believe that progress in the studies of the inequality-growth relationship, requires more effort in constructing appropriated databases that properly represent individual circumstances. In this respect, the European Union is carrying out the so-call surveys on living conditions since 2004 for the European countries (15 countries in 2004, 20 countries in 2005, 23 countries in 2006 
and 25 countries in 2007) so hopefully we will be able to contrast with a better database the main conclusions of this study in the future.

\section{References}

Aghion, P. and Bolton P. (1997), "A trickle-down theory of growth and development with debt overhang", Review of Economic Studies, 64, 151-162.

Aghion, P. Banerjee, A. and Pikkety, T. (1999), "Dualism and macroeconomic volatility", Quarterly Journal of Economics, 114, 1359-1397.

Alesina, A. and Rodrik, D. (1994), "Distributive politics and economic growth", Quaterly Journal of Economics, 109, 465-490.

Alesina, A. and Perotti, R. (1994), "The political economy of growth: a critical survey of the recent literatureò, The World Bank Economic Review, 8, 350-371.

Alesina, A. and Perotti, R. (1996), "Income distribution, political instability and investment", European Economic Review, 40, 1203-1228.

Alesina, A., Ozler, S., Roubini, N. and Swagel, P. (1996), "Political instability and economic growth", Journal of Economic Growth, 1, 189-211.

Banerjee, A. and Newman, A.F. (1991), "Risk-bearing and the theory of income distribution", Review of Economic Studies, 58, 211-235.

Barro, R. J. (1991), "Economic Growth in a Cross Section of Countries", Quarterly Journal of Economics, 106, 407- 443.

Barro, R. J. (2000), ñnequality and growth in a panel of countriesò, Journal of Economic Growth, 5, 5-32. 
Barro, R. J. and Sala-i-Martin, X (1991), ñConvergence Across States and Regionsò, Brookings Papers on Economic Activity, 1, 107-182.

Benabou, R. (1996a), "Inequality and Growth", NBER Macroeconomics Annual, 11, 1174.

Benabou, R. (1996b), "Unequal societies", NBER Working Paper 5583.

Bertola, G. (1993), ñFactor shares and savings in endogenous growthò, American Economic Review, 83, 1184-1210.

Betts, J. and J. E. Roemer (2006): ñEqualizing opportunity for racial and socioeconomic groups in the United States through educational finance reformò, forthcoming in P. Peterson (ed.), Schools and the Equal Opportunity Problem, Cambridge, M.A.: The MIT Press.

Bourguignon, F. (1981), ñPareto-superiority of unegalitarian equilibria in Stiglitz' model of wealth distribution with convex savings function", Econometrica, 49, 14691475.

Bourguignon, F. and Verdier, T. (2000), ñOligarchy, democracy, inequality, and growthò, Journal of Development Economics, 62, 285-313.

Clarke, G.R.C. (1995), ñMore evidence on income distribution and growthò, Journal of Development Economics, 47, 403-427.

Dasgupta, P. and Ray, D. (1987), ñnequality as a Determinant of Malnutrition and Unemployment Policyò, Economic Journal, 97, 177-188.

Ehrhart, C. (2009), ñThe effects of inequality on growth: a survey of the theoretical and empirical literatureò, ECINEQ WP 2009-107.

Fleurbaey, M. (1995): ñEqual opportunity or equal social outcomeò, Economics and Philosophy, 11, pp. 25-56. 
Fleurbaey M. and F. Maniquet (2007): ñCompensation and responsibilityò, in The Handbook for Social Choice and Welfare, Arrow, K., Sen, A. and Suzumura, K. (eds.), Amsterdan: North Holland.

Forbes, K. (2000), ñA reassessment of the relationship between inequality and growthò American Economic Review, 90, 869-887.

Galenson, W. and Leibenstein, H. (1955), ñnvestment Criteria, Productivity and Economic Developmentò, Quaterly Journal of Economics, 343-370.

Galindo, M.A. (2004), ñDistribución de la renta, crecimiento y política fiscalò Papeles de Trabajo, 25/04, Instituto de Estudios Fiscales.

Galor, O. and Zeira, J. (1993), "Income distribution and macroeconomics", Review of Economic Studies, 60, 35-52.

González-Páramo, J.M. (1994), "Gasto Social y Crecimiento Económico en el Estado del Bienestar", Hacienda Pública Española, Monografía núm. 2, 135-153.

Kuznets, S. (1955), "Economic growth and income inequality", American Economic Review, 45, 1-28.

Lefranc, A., Pistolesi, N. and A. Trannoy (2006a): ñEquality of opportunity: Definitions and testable conditions, with an application to income in Franceò, ECINEQ working paper 2006-53.

Lefranc, A., Pistolesi, N. and A. Trannoy (2006b): ñnequality of opportunities vs. inequality of outcomes: Are Western societies all alike?ò, ECINEQ working paper 2006-54.

Lucas, J. R. (1995), Responsibility, Oxford: Clarendon Press.

Mason, A. (1988), ñSavings, Economic Growth and Demographic Changeò, Population and Development Review, 14 (1), 113-144. 
Marshall, A. (1988), ñncome Distribution, the Domestic Market and Growth in Argentinaò Labour and Society, 13 (1), 79-103.

Milanovic, B. (2000), ñThe median-voter hypothesis, income inequality, and income redistribution: an empirical test with the required dataò European Journal of Political Economy, 16, 367-410.

Mirrless, J. (1971), òAn exploration in the theory of optimum income taxationò Review of Economic Studies, 38, 175-208.

Moreno-Ternero, J. D. (2007): ñOn the design of equal-opportunity policiesò, Investigaciones Económicas, 31, pp. 351-374.

Ooghe, E., Schokkaert E. and D. Van de gaer (2007): ñEquality of opportunity versus equality of opportunity setsò, Social Choice and Welfare, 28, pp. 209-230.

Partridge, M.D. (1997), ñIs Inequality Harmful for Growth? Commentò, American Economic Review, Vol. 87, No. 5, pp. 1019-1032

Peragine, V. (2002): ñOpportunity egalitarianism and income inequalityò, Mathematical Social Sciences, 44, pp. 45-60.

Peragine, V. (2004), ñRanking of income distributions according to equality of opportunityò, Journal of Income Inequality, 2, 11-30.

Perottti, R. (1992), "Income distribution, politics and growth", American Economic Review $82,311-316$

Perottti, R. (1993), "Political equilibrium, income distribution and growth", Review of Economic Studies, 60, 755-776.

Perottti, R. (1996), "Growth, income distribution and democracy: what the data say", Journal of Economic Growth, 1, 149-187.

Persson, T. and Tabellini, G. (1994), "Is inequality harmful for growth?: theory and evidence", American Economic Review, 84, 600-621. 
Partridge, M. (1997), ñis inequality harmful for growth? Commentò, American Economic Review, 87, 1019-1032.

Rebelo, S. (1991), ñLong-run policy analysis and long-run growthò, Quaterly Journal of Economics, 107, 255-284.

Roemer, J. E. (1993): ñA pragmatic approach to responsibility for the egalitarian plannerò, Philosophy \& Public Affairs, 10, pp. 146-166.

Roemer, J.E. (1996), Theories of Distributive Justice, Harvard University Press, Cambridge, M.A.

Roemer, J.E. (1998), Equality of Opportunity, Harvard University Press, Cambridge, M.A.

Roemer, J.E. (2002), ñEquality of opportunity: a progress reportò, Social Choice and Welfare, 19, 455-471.

Roemer, J.E., Aaberge, R., Colombino, U., Fritzell, J., Jenkins, S., Marx, I., Page, M., Pommer, E., Ruiz-Castillo, J., San Segundo, M. J., Tranaes, T., Wagner, G. and Zubiri, I. (2003), ñTo what extent do fiscal regimes equalize opportunities for income acquisition among citizens?ò, Journal of Public Economics, 87, 539565.

Rodríguez, J. G. (2008), ñPartial equality-of-opportunity orderingsò, Social Choice and Welfare, 31, 435-456.

Ruiz-Castillo, J. (2003), ñThe measurement of the inequality of opportunitiesò, Research on Economic Inequality, 9, 1-34.

Saint-Paul, G. and Verdier, T. (1996), ñnequality, redistribution and growth: a challenge to the conventional political economy approachò, European Economic Review, 60, 719-728. 
Stiglitz, J.E. (1969), ñThe distribution of income and wealth among individualsò, Econometrica, 37, 382-397.

Szekeli, M. and Hilgert, M. (1999), ñThe 1990s in Latin America: Another decade of persistent inequalityò, Working Paper 410, IDB-OCE.

Todaro, M.P. (1997), Economic development, Longman, London.

Van de Gaer, D. (1993): r̃̃Euality of opportunity and investment in human capitalò, Catholic University of Leuven, Faculty of Economics, no. 92.

U.S. Bureau of the Census, Department of Commerce. Decennial census of population: Characteristics of the population. Washington, DC: U.S. Government Printing Office, various years.

U.S. Department of Agriculture. Agricultural statistics. Washington, DC: U.S. Government Printing Office, various years.

U.S. Department of Commerce. Government finances. Washington, DC: U.S. Government Printing Office, various years.

U.S. Department of Labour. Employment, hours and earnings. Washington, DC: U.S. Government Printing Office, various issues.

U.S. Department of Labour. Geographic profile of employment and unemployment. Washington, DC: U.S. Government Printing Office, various years.

Zou, H. and Li, H. (1998), ñncome inequality is not harmful for growth: theory and evidenceò, Journal of Development Economics, 2, 318-334. 